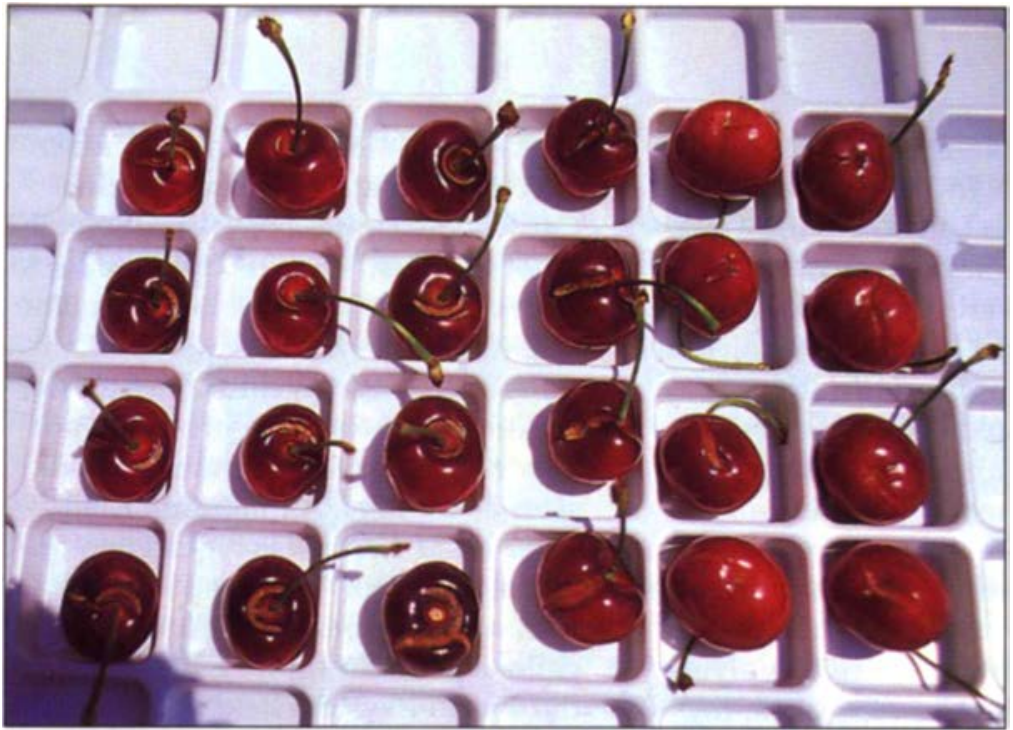

Rain cracking usually occurs where water accumulates and remains on cherries. Cracks typically appear at the pedicel ( 3 left columns), the suture (4th column) and the stylar end (last 2 columns) where droplets of water hang on fruit.

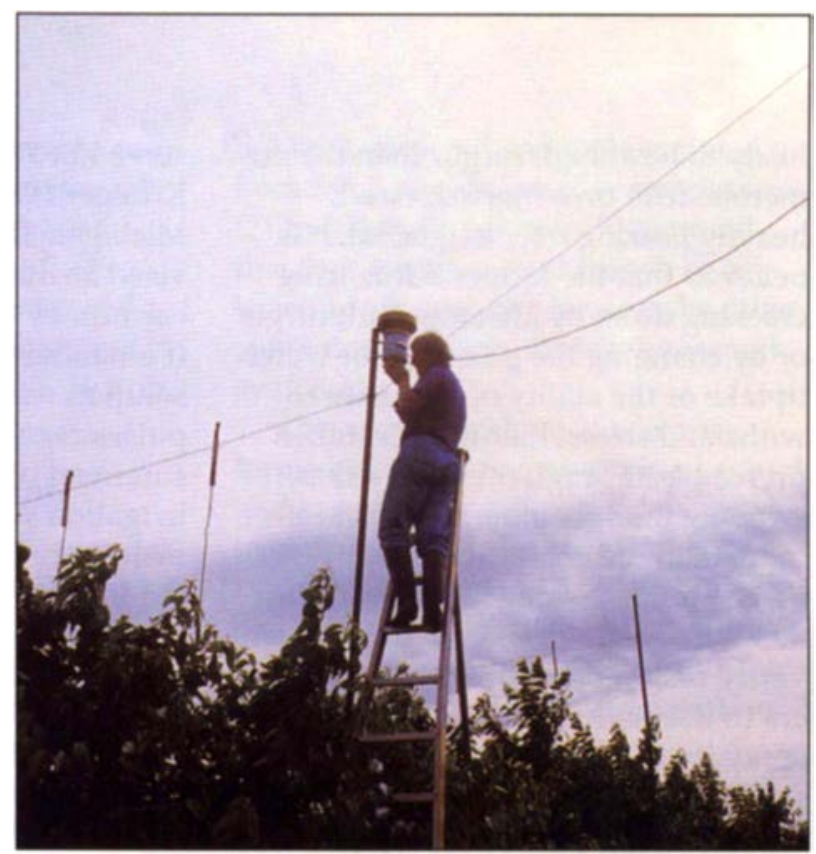

Pomologist Steve Southwick checks a tipping rain gauge that will activate the overtree sprinkling system after $0.1 \mathrm{~mm}$ of rainfall.

\section{Rain cracking of sweet cherry} fruit is a worldwide problem and has resulted in substantial crop losses of California cherries in each of the past 4 years (19931996). Various strategies to reduce cracking have provided inconsistent results. During 1996, however, rain-timed applications of calcium chloride $\left(\mathrm{CaCl}_{2}\right)$ via overtree sprinklers reduced the overall percentage of rain-cracked 'Bing' cherry fruit by nearly half at three locations in the Central Valley. Although these results were obtained in only one season, their consistency across sites is encouraging. In addition, a preliminary observation suggests this calcium treatment may also reduce postharvest disorders of rain-exposed fruit without affecting fruit firmness, size or weight. Some marginal leaf necrosis was noted at one site, suggesting that application rates may need to be adjusted. Overtree delivery of calcium chloride during rain provides the potential for cherry growers to reduce fruit cullage from rain. While the setup and operational costs are substantial, the increases in marketable fruit may make this system a profitable investment.

\title{
Calcium chloride reduces rain cracking in sweet cherries
}

\author{
Michael Rupert $\square$ Stephen Southwick a Kitren Weis \\ John Vikupitz $\square$ James Flore $\square$ Hong Zhou
}

In California, sweet cherries (Prunus avium $\mathrm{L}$.) are grown on a substantial commercial scale in the Central Valley from Arvin to Marysville and in some coastal valleys, especially in Santa Clara and San Benito counties. The largest volume of cherry production occurs in the Stockton/Lodi region. The California Cherry Advisory Board estimates the statewide cherry crop is worth roughly $\$ 80$ million annually. Moderate to severe losses from rain occurred throughout the state in 1996, with losses estimated as high as $30 \%$ in the Stockton/Lodi region. The California cherry industry also suffered losses from rain damage in each of the previous 3 years (1993-1995).

Fruit cracking or splitting is the major cause of economic loss, but rain damage also includes fruit softening, discoloration and increased decay, resulting in reduced fruit quality, marketability, and consumer confidence. U.S. Department of Agriculture and
California Department of Food and Agriculture records over the past 30 years show that rain occurs during cherry-maturation and harvest about 2 out of 10 years in the cherry growing areas of the Central Coast, where maturation occurs relatively late (June), and as often as 7 out of 10 years in areas of the southern San Joaquin Valley, where maturation occurs very early (April), and in the wetter regions of the Sacramento Valley, usually harvested in May. In the Stockton/Lodi region, rain occurs about 5 out of 10 years during the critical maturation and harvest period in May.

Factors that may influence severity of cracking include cultivar, fruit maturity stage, crop load, fruit firmness, orchard irrigation status, duration of rainfall, and temperature.

It is thought that smaller crop load increases the potential for cracking in a given cultivar because the fewer fruit on a lightly bearing tree are more 
likely to be at high turgor than the numerous fruit on a more stressed, heavily bearing tree. In general, it is believed that the factors influencing cracking do so by affecting fruit turgor or by changing the potential for water uptake or the ability of fruit skin to withstand stress. Rainwater is taken up readily through the cherry skin, swelling the subepidermal flesh cells more than the epidermal cells.

The longer water remains in contact with the fruit, the greater the severity of cracking, prompting growers to use helicopters or air blast sprayers to blow water off fruit as soon as possible after rain. These efforts are expensive and only partially effective. Physical barriers to rain (e.g., orchard rain covers) have also been used to prevent cracking. Other efforts, such as sprayer application of compounds that reduce the osmotic potential of rainwater (e.g., calcium) or antitranspirants to reduce water uptake, have had only partial and variable success in reducing rain-induced fruit cracking.

Calcium is known to decrease the permeability of cell membranes. In one study, dipping cherries in calcium solutions was found to decrease the water uptake rate and cracking index of the fruit by $15 \%$ to $30 \%$ (Ackley 1956). Calcium must be applied directly to the fruit surface for effective control, however, because translocation from the leaves to the fruit is minimal. Furthermore, to interfere with direct water uptake during rain, it is thought that calcium must remain on the fruit while rainwater is present. In addition to reducing rain-induced cracking, calcium applications may reduce postharvest disorders such as fruit pitting and decay.

In the 1970s, in an experiment designed to induce cracking under orchard conditions in California, UC Davis pomologist K. Uriu observed that cracking due to natural rainfall was actually reduced when overtree sprinklers were used prior to rainfall. He speculated that salts in the irrigation water accumulated on the fruit and reduced water uptake, resulting in little or no cracking during subsequent rains. The same phenomenon was ob- served in Washington (Ackley and Krueger 1980). In 1994, researchers at Michigan State University (MSU) devised an automated system to apply calcium by overtree irrigation (Fernandez and Flore 1995). Calcium solution was applied in automatic pulses regulated by continuous measurement of rainfall. This automated irrigation system could, in theory, maintain a layer of calcium solution on the fruit surface regardless of the rate or amount of rainfall. Automated overtree irrigation systems applying solutions of $0.5 \%$ to $1.0 \% \mathrm{CaCl}_{2}$ (by weight in tank mixture) were tested in Michigan in 1994-1995 and in Washington in 1995. Rain-induced fruit cracking was reduced in one Michigan trial from $33 \%$ in untreated trees to $11 \%$ in treated trees. In two Washington trials, the $\mathrm{CaCl}_{2}$ treatment reduced cracking from $20 \%$ to $4 \%$ and from $8 \%$ to $2 \%$. In Washington, average fruit size decreased by 0.3 to $1.5 \mathrm{~g}$ with $\mathrm{CaCl}_{2}$ treatment, but statistical analyses were not presented with these data. Based on the preliminary success of this previous work, we decided to set up several demonstration sites in California to test automated raintimed delivery of $\mathrm{CaCl}_{2}$.

\section{Rain-activated overtree delivery}

With the assistance of growers, three commercial 'Bing' cherry (Prunus avium L.) orchards near Lodi were equipped with rain-activated overtree sprinkler systems for the automatic delivery of $\sim 0.5 \% \mathrm{CaCl}_{2}$ (Moraleaf, $94 \% \mathrm{CaCl}_{2}$ ) during rain events. (Concentrations of $\mathrm{CaCl}_{2}$ solutions are given as percentage of $\mathrm{CaCl}_{2}$ by weight.) Rains were heavy in 1996, giving us an opportunity to validate and demonstrate the effectiveness of our treatment. At each location, a rain sensor (Texas Electronics TRP-525) measured rainfall and a Campbell Scientific CR-10 controller automatically activated a 12-volt DC-powered solenoid valve to turn on overtree sprinklers. Software provided by Jim Flore (MSU) recorded rain amounts and valve activations and controlled the duration and timing of treatments. Concentrated $\mathrm{CaCl}_{2}$ solution ( 15\%) was injected into irrigation lines from a 100-gallon stock tank via a Venturi injector calibrated to provide a final $\mathrm{CaCl}_{2}$ concentration of $\sim 0.5 \%$. Solubility of $\mathrm{CaCl}_{2}$ is $74.5 \mathrm{~g} / 100 \mathrm{ml}$. In order to deliver the desired $0.5 \%$ concentration of $\mathrm{CaCl}_{2}$, each system required a different-capacity Venturi injector depending on the system pressure and flow rate as well as the numbers and sizes of emitters. A minimum head pressure of 45 psi was required to operate the Venturi injector and allow a total sprinkler outflow of up to 550 gallons per hour (gph). Even though the overtree system hardware varied slightly at different locations, the calibrated delivery concentration of $\mathrm{CaCl}_{2}$ was uniform across all three locations.

During a rain event, the controller was programmed to activate the sprinkling system for 10 minutes after the first $0.1 \mathrm{~mm}$ of measured rainfall. Thereafter, $1.3 \mathrm{~mm}$ of rainfall was needed to reactivate the sprinklers for each additional 10-minute period. After a 1-hour period with no measured rainfall, the system would reset to begin a new cycle after the next $0.1 \mathrm{~mm}$ rainfall episode.

At each location, we selected a uniform population of adjacent trees and installed overtree sprinklers to treat a portion of the trees. The surrounding, untreated trees were used as controls. Flex risers off the main irrigation line were connected to 0.625 -inch plastic tubing that was placed down each row of trees. Two microsprinklers per tree were then connected by 15 - to 20 -foot lengths of spaghetti tubing, suspended on poles or wire about 18 inches above the canopy and positioned several feet from either side of the tree center. Because tree size varied among orchard locations, sprinkler capacity and placement were adjusted to give adequate tree coverage at each location. During the study, Moraleaf was freshly mixed in tanks or stirred vigorously just prior to the initial rainfall at all three locations and then stirred two or three more times thereafter during the 7-day rainy period.

Location 1. OG Packing orchard off Alpine Rd. in Stockton contained 31 treated and 33 untreated 'Bing' trees on 'Mahaleb' (Prunus mahaleb) or 'Stockton Morello' (Prunus cerasus) 
rootstock and 17 pollenizer trees of 'Burlat', 'Van', 'Rainier' and 'Hardy Giant'. The orchard was 14 years old, had a medium crop compared to previous years and had been treated with gibberellic acid (GA) to delay maturity and improve fruit size and firmness. Irrigation was by buried drip and trees were adequately watered although the soil surface was dry. Trees were approximately 12 feet tall with 17-foot-by18-foot spacing. Two microsprinklers, each with output rates of $5.5 \mathrm{gph}$, were placed beside each tree on poles 4 feet from either side of the trunk. To deliver $0.5 \% \mathrm{CaCl}_{2}$, this system required a 1/2-inch, $17 \mathrm{gph}$ Venturi injector and a stock solution of $15 \% \mathrm{CaCl}_{2}$ obtained by mixing 135 pounds of Moraleaf with irrigation water to make 100 gallons.

Location 2. The Mohr-Fry

Ranches/Felix Costa and Sons, Inc. orchard off Hwy. 88 in Lodi contained very large, spreading 'Bing' trees on 'Mahaleb' rootstock. At this location, 10 treated and 12 untreated trees were included in the study, as well as one 'Burlat' tree. Pollenizers for this orchard were 'Burlat' and 'Black

Tartarian'. The orchard was at least 30 years old and bore a medium crop. Irrigation by microsprinklers had occurred several days earlier, and the trees were adequately watered although the soil surface was dry prior to the initial rain. Trees had been topped to about 17 feet tall and were planted at 18-foot-by-30-foot spacing. Two microsprinklers, each with 12.5 gph output rates, were placed on poles 6 feet from either side of the trunk. To deliver $0.5 \% \mathrm{CaCl}_{2}$ to the trees, a $17 \%$ stock solution (150 lb Moraleaf / 100 gal water) and a 1/2-inch, 10 gph Venturi injector were used for the lower outflow rate of this system. An in-line booster pump was also installed to provide sufficient pressure to operate the sprinklers.

Location 3. The A. Sambado \& Sons, Inc. orchard off E. Comstock Road in Linden contained 21 treated and 15 untreated 'Bing' trees on 'Mazzard' (Prunus avium) rootstock, as well as two 'Burlat' pollenizers. The 8year-old orchard bore a light crop. The trees, approximately 12 feet tall with 18-foot by 20 -foot spacing, were irri- gated by microsprinklers prior to rainfall. Two $5.5 \mathrm{gph}$ microsprinklers were suspended from wires 6 feet apart above each tree. To deliver a $0.5 \%$ $\mathrm{CaCl}_{2}$ solution to the trees, we used a $14 \%$ stock solution (125 lb Moraleaf/ $100 \mathrm{gal}$ water) and a 1/2-inch, $10 \mathrm{gph}$ Venturi injector.

\section{Evaluation of fruit cracking}

Initial cracking percentage was determined on May 17 at all locations by counting the numbers of cracked and total fruit from base to terminus of one representative branch on each treatment and control tree. Branches ranged in circumference from 4 to 14 inches and in length from 39 to 118 inches. Each branch included a range of fruit maturity stages. The fruit evaluated from a single branch accurately represented the whole tree because fruit was evaluated along the whole branch and because fruit load and development range on the branch was observed to be consistent with that of the tree as a whole. We chose branches prior to rain. Any split in the fruit extending through all layers of the epidermis to expose fruit flesh was considered a crack.

Five days after the initial "on tree" evaluation of cracking, fruit from previously evaluated branches at Locations 1 and 2 was harvested and re-evaluated for cracking. Fruit at Location 3 was harvested for packing and was not reevaluated. For this second evaluation, fruit was first graded into maturity classes based on color standards used by the California cherry industry (straw, light red, dark red and mahogany). At Location 2, slightly smaller sample sizes (21 to 100 fruits per branch) required that fruit from a second branch be collected to adequately represent the different maturity classes during the second evaluation.

This second evaluation was performed to compare maturity classes and to determine if more cracks developed over time in fruit already affected by rain as it was exposed to a combination of additional rain, rising temperatures, more intense sunlight and further $\mathrm{CaCl}_{2}$ treatment. This was important, because some growers choose to delay harvest after rain until sufficient dry weather has allowed waterlogged fruit to return to normal turgor and immature fruit to ripen. Thus, the 7-day period between initial rain and re-evaluation was representative of a common grower strategy after heavy rain, especially when additional harvests are required for fruit that is not at optimum maturity during initial harvest.

\section{Fruit quality evaluation}

All the fruit from evaluated branches at Location 1 was harvested 7 days after the initial $\mathrm{CaCl}_{2}$ application and evaluated for the effects of treatment on fruit size, firmness and postharvest disorders. A random sample of 10 fruit from each tree (31 treated trees, 33 control trees) was tested for firmness using a Momentum Transfer Generator (MTG) firmness instrument, which gives a unitless measure of fruit firmness. We then graded fruit for weight and size.

\begin{tabular}{|c|c|c|c|c|c|c|c|c|c|}
\hline \multirow[t]{2}{*}{ Location } & $\begin{array}{l}\text { Total } \\
\text { rain }\end{array}$ & $\begin{array}{l}\text { No. overtree } \\
\text { sprinkler } \\
\text { activations }\end{array}$ & $\begin{array}{c}\text { Time } \\
\text { system } \\
\text { on }\end{array}$ & $\begin{array}{c}\text { Maximum } \\
\text { Venturi } \\
\text { draw }\end{array}$ & $\begin{array}{c}\text { Actual } \\
\text { Venturi } \\
\text { draw }\end{array}$ & t value & $\begin{array}{c}\text { Cracking, } \\
\text { control }\end{array}$ & $\begin{array}{c}\text { Cracking, } \\
\mathrm{CaCl}_{2} \\
\text { treatment }\end{array}$ & $\begin{array}{c}\text { Reduction } \\
\text { in } \\
\text { cracking }\end{array}$ \\
\hline & inches & & $\min$ & gal & gal & & $\%$ & $\%$ & $\%$ \\
\hline 1 & 1.24 & 24 & 240 & 68 & 68 & $5.5(63)^{*}$ & $14.5(1.8) \dagger$ & $5.0(1.9) \ddagger$ & 9.5 \\
\hline 2 & 1.16 & 19 & 190 & 30 & 15 & $2.1(20)$ & $17.8(3.3)$ & $9.1(3.6) \S$ & 8.7 \\
\hline \multirow[t]{2}{*}{3} & 2.44 & 39 & 390 & 65 & 30 & $2.5(34)$ & $38.5(3.0)$ & $24.2(2.5) \S$ & 14.3 \\
\hline & & & & \multicolumn{3}{|c|}{ Average } & $23.6(1.6)$ & $12.8(1.6)$ & 10.8 \\
\hline \multicolumn{10}{|c|}{$\begin{array}{l}\text { Degrees of freedom in ( ). } \\
\dagger \text { Standard error in ( ). } \\
\text { tControl and treatment significantly different }(P \leq 0.05) \text { by } t \text {-test within locations of arcsin square root } \\
\text { transformed data. } \\
\text { §Control and treatment significantly different }(P \leq 0.001) \text { by } t \text {-test within locations of arcsin square root } \\
\text { transformed data. }\end{array}$} \\
\hline
\end{tabular}


In addition to causing cracks, rain can induce or hasten postharvest decay, fruit softening and physiological disorders such as browning of otherfruit from Location 1 was graded to provide a preliminary assessment of the effect of rain-timed $\mathrm{CaCl}_{2}$ application on postharvest cherry decay and rain-induced physiological disorders. After being graded for firmness, weight and size, random samples totaling approximately 1,500 fruit from $\mathrm{CaCl}_{2}$ treated and control trees were selected and held at $32^{\circ} \mathrm{F}$ for 6 days and then graded for signs of postharvest disorders.

\section{Data analyses}

As required with binomial percentage data, all cracking percentages were transformed for analysis by taking the arcsin of the square root. Only data from 'Bing' trees were used for analyses. T-tests were performed for comparison of initial cracking percentages between $\mathrm{CaCl}_{2}$ treated and control trees within locations (table 1). For the second evaluation, cracking percentages between treatment and control within each maturity class and within each location were compared using the transformed data and oneway analysis of variance weighted by sample size (SAS GLM weighted procedure, table 2). Treatments were the main effect, with variability among trees serving as the error term. Comwise undamaged fruit. A subsample of

parisons of fruit firmness size and weight between treated and control fruit were made using t-tests.

\section{Rainfall and system operation}

During the 1996 cherry harvest season, the Lodi area received rain showers intermittently for 7 days (May 1421). Although the three orchard locations were within a 5-mile radius, each received different amounts of rainfall, and therefore each system operated for a different duration (table 1). During the 7-day rainy period, Location 1 received 1.24 inches of measurable rainfall, which activated the $\mathrm{CaCl}_{2}$ delivery system for a total of $240 \mathrm{~min}$ utes. Location 2 received 1.16 inches of rain and the system operated for 190 minutes. Location 3 received about twice as much rainfall, 2.44 inches, and the system operated for 390 minutes.

The Venturi injector at Location 1 operated at its maximum rate of 17 gph to deliver 68 gallons of $15 \% \mathrm{CaCl}_{2}$ solution into the main line, where it was diluted with water and delivered onto trees. At Locations 2 and 3, lower outflow rates and perhaps lower system pressures did not allow the Venturi injectors to operate at their maximum rate of $10 \mathrm{gph}$ throughout each 10 minute cycle. At these locations, injection rate decreased as lines filled and line pressures stabilized. This gave about 5 minutes of maximum Venturi operation during each 10-minute cycle,

TABLE 2. Second evaluation of \% cherry fruit cracking in 'Bing' cherry after 7 days of intermittent rainfall at Locations 1 and 2 near Lodi, May 1996

\begin{tabular}{|c|c|c|c|c|c|}
\hline & $\begin{array}{l}\text { Fruit maturity } \\
\text { by color class* }\end{array}$ & $\begin{array}{l}\text { No. of fruit } \\
\text { sampled }\end{array}$ & $\begin{array}{l}\text { Cracking, } \\
\text { control }\end{array}$ & $\begin{array}{c}\text { Cracking, } \\
\mathrm{CaCl}_{2} \text { treated }\end{array}$ & $\begin{array}{c}\text { Reduction in } \\
\text { cracking }\end{array}$ \\
\hline & & & ..................... & \% & .................. \\
\hline Location 1 & $\begin{array}{l}\text { straw } \\
\text { light red } \\
\text { dark red } \\
\text { mahogany } \\
\text { Total \% cracked }\end{array}$ & $\begin{array}{r}68 \\
1,136 \\
2,379 \\
1,591 \\
5,174\end{array}$ & $\begin{array}{c}21.2(14.2) \dagger \\
34.7(6.7) \\
35.6(4.1) \\
46.0(5.2) \\
38.9(4.0)\end{array}$ & $\begin{array}{l}22.2(9.8) \\
19.8(4.9) \\
25.5(3.4) \ddagger \\
36.6(4.3) \\
27.5(3.4) \ddagger\end{array}$ & $\begin{array}{r}-1.0 \\
14.9 \\
10.1 \\
9.4 \\
11.4\end{array}$ \\
\hline Location 2 & $\begin{array}{l}\text { straw } \\
\text { light red } \\
\text { dark red } \\
\text { mahogany } \\
\text { Total \% cracked }\end{array}$ & $\begin{array}{r}38 \\
167 \\
679 \\
1,339 \\
2,223 \\
\end{array}$ & $\begin{array}{c}0(0) \\
21.3(7.3) \\
31.3(4.8) \\
43.8(4.2) \\
38.3(4.1)\end{array}$ & $\begin{array}{c}23.6(16.0) \\
13.7(7.1) \\
19.1(4.1) \\
26.0(4.5) \S \\
24.2(3.6) \S \\
\end{array}$ & $\begin{array}{r}-23.6 \\
7.6 \\
12.2 \\
17.8 \\
14.1\end{array}$ \\
\hline
\end{tabular}

"Fruit cracking evaluated in four fruit maturity classes and averaged for all fruit. †Standard error in ().

$\mp$ Control and treatment significantly different at $\mathrm{P} \leq 0.05$ within maturity classes, within locations, by one-way ANOVA of arcsin square root transformed data, weighted by the square root of the sample size. $\S$ Control and treatment significantly different at $\mathrm{P} \leq 0.01$ within maturity classes, within locations, by oneway ANOVA of arcsin square root transformed data, weighted by the square root of the sample size. reducing the amount of $\mathrm{CaCl}_{2}$ that was applied to the trees during the last half of each cycle (table 1). Despite lowerthan-expected duration of $\mathrm{CaCl}_{2}$ delivery, treatments at Locations 2 and 3 were effective at reducing rain cracking. The $\mathrm{CaCl}_{2}$ treatment was even more effective when the system operated properly, as it did at Location 1 (table 1).

\section{Reduction of rain cracking}

Incidence of rain cracking was significantly reduced at all locations from an average of $23.6 \%$ cracking in the controls to $12.8 \%$ in the treatments - despite the decreased Venturi injection rates at Locations 2 and 3 (table 1). As expected, each location differed in both amount of cracking and reduction of cracking. A number of factors could account for the differences, including differing amounts and durations of rainfall, differences in system operation, and differences in tree ages, crop load, orchard water status, application of GA at Location 1, pruning and other cultural practices. However, the automated rain-timed application of $\mathrm{CaCl}_{2}$ was effective at significantly reducing rain cracking under the wide range of conditions observed at the three different locations. This effectiveness across a range of conditions, as well as results from Michigan and Washington, indicates that automated overtree application of $\mathrm{CaCl}_{2}$ has the potential to consistently reduce rain cracking in sweet cherry under varied orchard conditions. Previous efforts using other delivery strategies and a variety of chemicals have never obtained this level of consistency in cracking reduction.

\section{Changes in cracking over time}

Comparison of tables 1 and 2 shows that 5 days after the initial evaluation, the total percentage of cracked fruit had increased by $10 \%$ to $25 \%$ on both treated and untreated trees at Locations 1 and 2. Nevertheless, the total percentage of cracked fruit was still significantly lower on treated trees than on control trees at the second evaluation.

Within maturity classes, the $\mathrm{CaCl}_{2}$ treatment resulted in significantly decreased levels of cracking in dark red 
fruit at Location 1 and mahogany fruit at Location 2 (table 2). More mature or darker 'Bing' fruit tended to exhibit higher cracking levels than less-mature or lighter fruit. Samples from these locations consisted mostly of mature fruit in the dark red and mahogany classes. It appears our treatment had the greatest effect on these mature fruit, which are most susceptible to cracking.

Subsamples of straw-colored and light red fruit had smaller numbers of fruit and high variation for cracking within treatments, resulting in no significant differences between treatments for these two maturity classes. The increase in cracking percentage for straw fruit, although not statistically significant, is of some concern but is probably the result of sampling error rather than treatment effects. Sample size for straw fruit was particularly small and represented few trees, so numerical differences between treatment and control levels of cracking for this category should be interpreted with caution until more data can be collected.

\section{Fruit quality}

No significant difference in firmness, size or weight of fruit was detected between treatment and control trees at Location 1. Mean MTG firmness values for treated and untreated fruit at Location 1 were 998.4 (standard error of mean [S.E.] $=11.0$ ) and 997.8 (S.E. =9.4), respectively. Mean size for treated fruit was $25.0 \mathrm{~mm}$ (S.E. $=0.09)$ versus $25.1 \mathrm{~mm}($ S.E. $=0.09)$ for untreated fruit. A diameter of 1 inch is equivalent to row size 10, a designation used in commercial cherry grading. Mean weight for treated fruit was $7.7 \mathrm{~g}$ (S.E. $=0.07$ ) versus $7.9 \mathrm{~g}$ (S.E. $=$ 0.07 ) for untreated fruit.

At Location 1, 2.8\% of 885 uncracked fruit from control trees showed signs of postharvest disorders or decay, including hard brown areas that became soft and sunken after several hours at room temperature. In contrast, from a sample of 542 fruit treated with $\mathrm{CaCl}_{2}$, no fruit showed any sign of postharvest disorders or decay. This preliminary finding suggests that rain-timed $\mathrm{CaCl}_{2}$ application should be assessed further as a poten- tial method for reducing postharvest decay and rain-induced disorders of cherries in conjunction with reduction of rain cracking. Perhaps by decreasing uptake of water into subepidermal cells, $\mathrm{CaCl}_{2}$ lessened the degree of fruit tissue or cell rupture and thereby decreased the potential for postharvest disorders and decay.

At Location 1, some necrosis of leaf edges occurred on treated trees, especially close to sprinkler heads where $\mathrm{CaCl}_{2}$ was probably most concentrated. Trees recovered fully from this effect, but modifications to application duration or concentration may reduce damage to foliage. This effect was not observed at the other locations where reduced Venturi flow rates delivered less $\mathrm{CaCl}_{2}$ to trees.

\section{Other benefits}

Other uses for an automated system may include temperature-activated frost protection during bloom and fruit development, as well as summer cooling during fruit bud differentiation to prevent double and spur fruit. (Double fruit are two fused fruit sharing a single stem, while a spur fruit consists of one healthy and one shriveled fruit sharing the same stem.) In addition, accumulated winter chilling hours could be increased by enhancing evaporative cooling through temperature-controlled overtree sprinkling. The low-volume microsprinklers used in this system deliver a fine mist, which may also prove to be appropriate for delivery of foliar nutrient sprays and other chemical applications.

\section{Setup costs}

Investment in an automated $\mathrm{CaCl}_{2}$ delivery system for prevention of rain cracking entails initial setup costs, sprinkler costs per acre and application costs per acre per hour. Initial setup costs for each orchard control
Applying calcium chloride to prevent rain cracking may also reduce postharvest decay, the brown spotting seen on these cherries.

system are $\$ 2,000$ to $\$ 3,000$, including labor. Over $\$ 1,000$ of this is the cost of a multipurpose scientific controller/ datalogger. Specialized relays, valves and the controller housing also account for much of the cost. These costs should eventually be reduced, assuming prefabricated controllers for this specific purpose become commercially available. Microsprinklers, tubing and an overtree suspension system would cost $\$ 1,000$ to $\$ 1,500$ per acre. Application of $0.5 \% \mathrm{CaCl}_{2}$ using two $5.5 \mathrm{gph}$ sprinklers per tree costs about $\$ 45$ per acre per hour. An hour of constant operation would require a steady rain of about $1 / 3$ inch per hour.

\section{Continuing research}

Automated rain-timed application of $\mathrm{CaCl}_{2}$ in a heavy rain year at three locations in California consistently reduced rain cracking in 'Bing' cherries and has potential for other related uses that could improve fruit quality and marketable yield. In future years, we plan to refine application rates, durations, timings and sprinkler distributions to obtain maximum reduction of rain cracking using $\mathrm{CaCl}_{2}$. We also plan to test other calcium formulations that have shown potential to reduce rain cracking. We will further assess the effects of $\mathrm{CaCl}_{2}$ on reduction of 
rain-induced postharvest disorders and investigate the potential for automated frost protection, evaporative cooling and foliar nutrient applications.

M. Rupert is Postgraduate Researcher, $S$. Southwick is Extension Pomologist, and K. Weis is Postgraduate Researcher, Department of Pomology, UC Davis; J.

Vikupitz is Product Manager, Netafim Irrigation, Inc., Fresno; J. Flore is Professor of Horticulture, Michigan State University; and H. Zhou is Statistician, Department of Statistics, UC Davis.

Special thanks for establishing orchard test sites go to Brad Kissler with MohrFry Ranches, Patrick Gottelli of OG Packing, Inc., and Lawrence Sambado and David Wyman of A. Sambado E Son, Inc. The authors would also like to thank Greg Costa of Felix Costa E Sons, Inc., Andy Mariani of Mariani Orchards, Fred Lagomarsino and Don Richardson of Lagomarsino Trust, Inc., and Jim Yeager, Al Bonin and Tony Cristler of the UC Davis Department of Pomology for their participation in and support of this project. Netafim Irrigation, Inc., of Fresno provided irrigation materials. Frank Younce of Pullman, Wash., provided Momentum Transfer Generator firmness instrument. Funding for this research was provided by the California Cherry Advisory Board.

Detailed instructions and materials lists for automated overhead sprinkler systems are available upon request from Michael Rupert, Dept. of Pomology, UC Davis, Davis, CA 95616, phone: (916) 754-4096, fax: (916) 752-8502, e-mail: merupert@ucdavis.edu

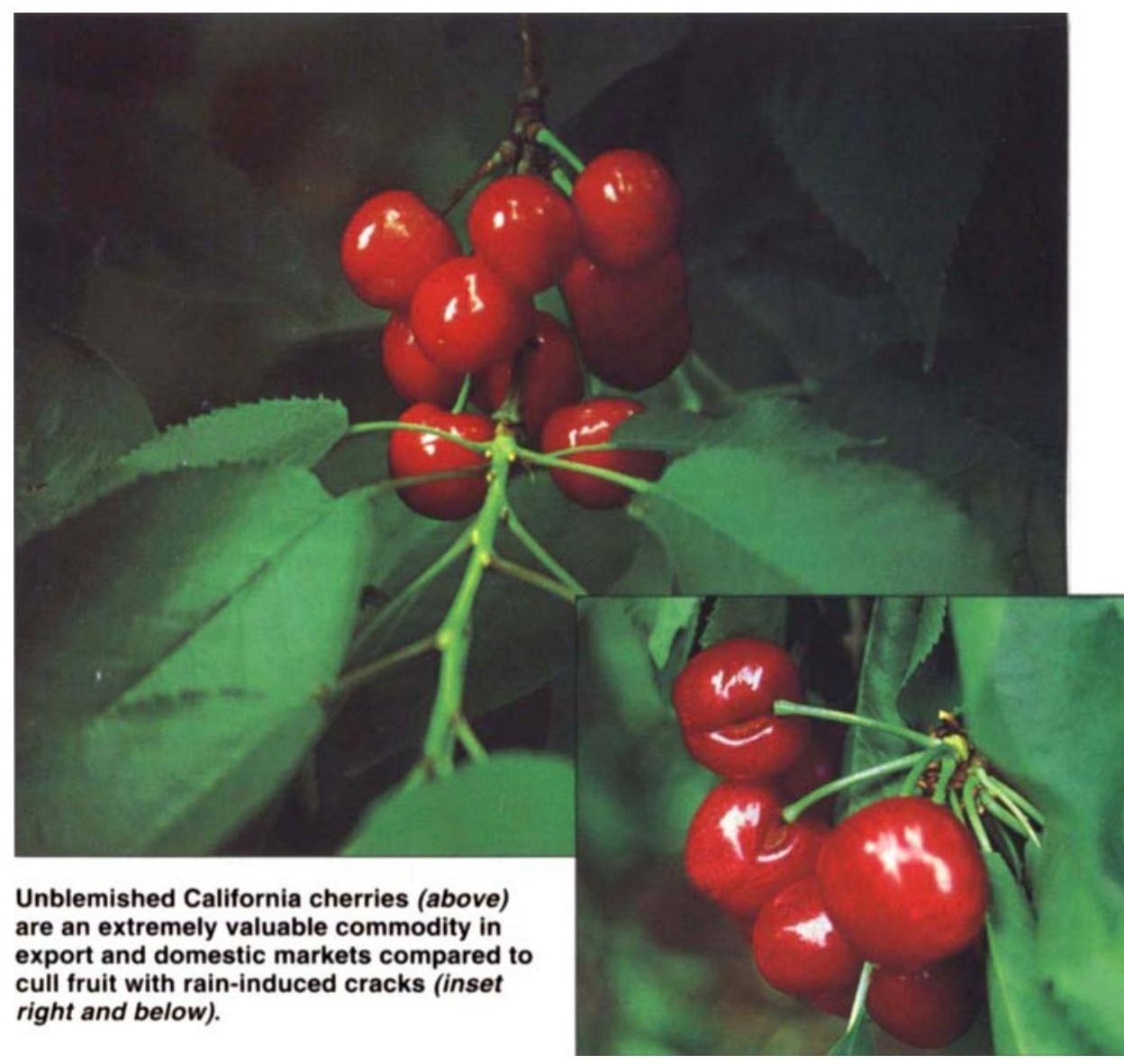

\section{References}

Ackley WB. 1956. Fruit cracking of sweet cherries. Washington State University Progress in Agriculture and Home Economics Research, Progress Report No. 9.

Ackley WB, Krueger WH. 1980.

Overhead irrigation water quality and the cracking of sweet cherries.

HortScience 15(3):289-98.

Fernandez RT, Flore JA. 1995. Intermittent $\mathrm{CaCl}_{2}$ sprays during rain to prevent sweet cherry cracking. HortScience 30(4):793.

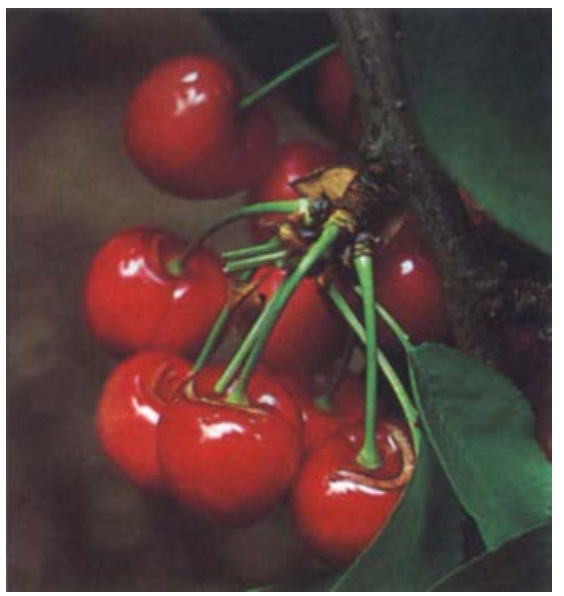

\section{CALIFORNIA AGRICULTURE ASSOCIATE EDITORS}

Animal, Avian, Aquaculture
\& Veterinary Sciences
Christopher M. Dewees
Kathryn Radke
Bennie I. Osburn
Barbara A. Reed
Economics \& Public Policy
Richard A. Howitt
Alvin Sokolow
Food \& Nutrition
Barbara Schneeman
Eunice Williamson

Human \& Community

\section{Development}

Linda M. Manton

Karen P. Varcoe

Land, Air \& Water Sciences

Garrison Sposito

Henry J. Vaux, Jr.

Natural Resources

Barbara H. Allen-Diaz

Daniel W. Anderson

Richard B. Standiford http://www.ucop.edu/anrhome/danr.htm

CALAG@ucop.edu

PH: (510) 987-0044

Pest Management

Edward G. Platzer

Joseph G. Hancock, Jr.

Michael K. Rust

Plant Sciences

Jodie S. Holl

Lee F. Jackson

G. Steven Sibbett 